\title{
Clinical Guidelines in Sports Medicine: Am I Reading a Guideline or a Consensus Statement: What's the Difference? Does it Matter?
}

Zuzana Machotka

University of South Australia, drzuzi@hotmail.com

Luke Perraton

Australia Catholic University

Karen Grimmer

University of South Australia, ubiquitous598@hotmail.com

Follow this and additional works at: https://nsuworks.nova.edu/ijahsp

Part of the Medicine and Health Sciences Commons

\section{Recommended Citation}

Machotka Z, Perraton L, Grimmer K. Clinical Guidelines in Sports Medicine: Am I Reading a Guideline or a Consensus Statement: What's the Difference? Does it Matter?. The Internet Journal of Allied Health Sciences and Practice. 2015 Jan 01;13(1), Article 11.

This Manuscript is brought to you for free and open access by the College of Health Care Sciences at NSUWorks. It has been accepted for inclusion in Internet Journal of Allied Health Sciences and Practice by an authorized editor of NSUWorks. For more information, please contact nsuworks@nova.edu. 


\title{
Clinical Guidelines in Sports Medicine: Am I Reading a Guideline or a Consensus Statement: What's the Difference? Does it Matter?
}

\begin{abstract}
Introduction: The integration of research evidence into clinical practice is one of the most challenging aspects of sports medicine. The time required to search library databases and read multiple systematic reviews represents a significant barrier to many clinicians. Clinical guidelines and consensus statements provide a summary of best practice for clinical conditions, and provide clinical recommendations. In sports medicine, the terms clinical guideline and consensus statement are often used interchangeably; however, important differences exist between these resources. The aims of this review were to identify the clinical guidelines published in key international sports medicine journals over the last five years, and assess their methodological quality. Methods: In March 2014, the top ten international sports medicine journals (identified on current impact factors) were searched using the single keyword 'guideline'. Peerreviewed papers providing clinical recommendations that were described by the authors as a guideline were included. The International Centre for Allied Health Evidence (iCAHE) guideline checklist, which consists of fourteen 'yes' and 'no' responses, graded 1 or 0 respectively, was used to assess the methodological quality of each clinical guideline. Results: Ten publications were retained from a pool of 34 potentially-relevant publications. The iCAHE guideline checklist scores ranged from 3 to 11 out of a possible 14 . Within the ten included publications, the most frequently identified methodological problems were a failure to describe the strategy used to search for evidence, failure to critically appraise the quality of underlying evidence and failure to clearly link the hierarchy and quality of underlying evidence to each recommendation. Discussion: The ten sports medicine journals included in this review published few clinical guidelines, and these were of poor to moderate quality. These clinical guidelines should be interpreted with caution because of methodological problems identified by this review. Consensus statements are useful resources for busy sports medicine clinicians; however, these resources should be subjected to the same rigorous appraisal as clinical guidelines, in order to identify areas where bias may potentially limit the usefulness of the recommendations.
\end{abstract}

\section{Author Bio(s)}

Suzan Machotka, MPhysio, is a Research Assistant at the International Center for Allied Health Evidence, at the University of South Australia, in Adelaide, South Australia.

Luke Perraton, PhD, is a Research Fellow at the Australia Catholic University in Melbourne, Victoria, Australia.

Karen Grimmer, PhD, is a Professor and Director of the International Centre for Allied Health Evidence, at the University of South Australia in Adelaide, South Australia. 


\title{
TIJAHSP
}

\section{The Internet Joưnal of Allied Health Sciences and Practice}

Dedicated to allied health professional practice and education

Vol. 13 No. 1 ISSN 1540-580X

\section{Clinical Guidelines in Sports Medicine: Am I Reading a Guideline or a Consensus Statement: What's the Difference? Does it Matter?}

\author{
Zuzana Machotka MPhysio ${ }^{1}$ \\ Luke Perraton $\mathrm{PhD}^{2}$ \\ Karen Grimmer $\mathrm{PhD}^{3}$
}

1. Research Assistant, International Center for Allied Health Evidence, University of South Australia, Adelaide, South Australia. Physiotherapist, Olympic Park Sports Medicine Centre, Melbourne, Victoria

2. Research Fellow, Australia Catholic University, Melbourne, Victoria

3. Professor and Director, International Center for Allied Health Evidence, University of South Australia, Adelaide, South Australia

Australia

\begin{abstract}
Introduction: The integration of research evidence into clinical practice is one of the most challenging aspects of sports medicine. The time required to search library databases and read multiple systematic reviews represents a significant barrier to many clinicians. Clinical guidelines and consensus statements provide a summary of best practice for clinical conditions, and provide clinical recommendations. In sports medicine, the terms clinical guideline and consensus statement are often used interchangeably; however, important differences exist between these resources. The aims of this review were to identify the clinical guidelines published in key international sports medicine journals over the last five years, and assess their methodological quality. Methods: In March 2014, the top ten international sports medicine journals (identified on current impact factors) were searched using the single keyword 'guideline'. Peer-reviewed papers providing clinical recommendations that were described by the authors as a guideline were included. The International Centre for Allied Health Evidence (iCAHE) guideline checklist, which consists of fourteen 'yes' and 'no' responses, graded 1 or 0 respectively, was used to assess the methodological quality of each clinical guideline. Results: Ten publications were retained from a pool of 34 potentially-relevant publications. The iCAHE guideline checklist scores ranged from 3 to 11 out of a possible 14. Within the ten included publications, the most frequently identified methodological problems were a failure to describe the strategy used to search for evidence, failure to critically appraise the quality of underlying evidence and failure to clearly link the hierarchy and quality of underlying evidence to each recommendation. Discussion: The ten sports medicine journals included in this review published few clinical guidelines, and these were of poor to moderate quality. These clinical guidelines should be interpreted with caution because of methodological problems identified by this review. Consensus statements are useful resources for busy sports medicine clinicians; however, these resources should be subjected to the same rigorous appraisal as clinical guidelines, in order to identify areas where bias may potentially limit the usefulness of the recommendations.
\end{abstract}

\section{INTRODUCTION}

Sports medicine encompasses aspects of human performance as well as injury assessment, diagnosis, management and prevention. Owing to its broad spectrum, sports medicine is often practiced within a multidisciplinary team involving professionals with different backgrounds and training who aim to optimise the care of an athlete. ${ }^{1}$ The professions that could be included in a sports medicine team are dependent on the setting, sport and availability. These professions can range from sports physicians, athletic trainers, physiotherapists and podiatrists, to nutritionists, psychologists, and massage therapists. ${ }^{1}$

Sports medicine clinicians are often required to make clear, decisive, on-the-spot decisions regarding the management and treatment of athletes. Pressures on athletes to return to sport are strong, and clear justification of management decisions are 
often demanded by third parties. In the past, sports medicine clinicians generally made their decisions based on clinical experience, and many had a rudimentary knowledge only of current research evidence. However, increasing requirements to justify management decisions, and an increasing number of stakeholders involved in the care of athletes has made the choice of evidence upon which a clinical decision is made critical.

Clinical guidelines offer a convenient way to provide comprehensive, best-evidence summaries for busy sports medicine clinicians, and can assist in evidence-informed decisions in the care of athletes. The move towards evidence-based practice has led to an increase in clinical guideline development in all fields of medicine. ${ }^{2,3}$ However, clinical guidelines are relatively new in the field of sports medicine. Previously, a barrier to the use of clinical guidelines was the concern that they may represent recipebased medicine and be a threat to professional autonomy. Sports medicine has been one of the last areas of clinical practice to adopt the concept of research-evidence-based care, as opposed to clinician expertise. However, clinical guidelines are now considered one of the major influences improving patient care. ${ }^{4}$

Well-constructed clinical guidelines should provide the most defensible evidence, as they should reflect a thorough unbiased search for, and quality appraisal of, current research evidence. Clinical guidelines should be developed within a rigorous evidence-based methodological framework, independent of developer vested interests, and the way they are written should support clinical decision making in practice. There has been international interest in establishing standard criteria for determining the quality of clinical guidelines, and as a result the Appraisal of Guidelines and Research Evaluation (AGREE) project was established in $1998 .{ }^{5}$

The AGREE instrument, now in its second edition (AGREE II), is a 23 part questionnaire (each question scored 1-7) which assesses guideline quality and takes approximately 15 minutes to complete. It requires two or more raters, and a weighted average of their scores is used to determine quality. A more recent tool has been introduced, the iCAHE Guidelines Critical Appraisal Instrument, ${ }^{6}$ which contains fourteen binary-scored items of key guideline quality issues. This instrument was designed for busy clinicians, administrators and policy-makers, and can be rated by one person in approximately five minutes. Recently the iCAHE guideline checklist has shown to provide a clinically-acceptable alternate to the AGREE II instrument. ${ }^{6}$

To understand the current availability and quality of sports medicine clinical guidelines available for sports medicine clinicians, this review aimed to 1) identify the top ten sports medicine journals based on current impact factors within the last five years, 2) quantify the articles which purported to reported clinical guidelines in the selected sports medicine journals, 3) assess the methodological quality of identified clinical guidelines, and 4) provide recommendations for the reporting and use of clinical guidelines in sports medicine practice.

\section{METHODS}

In March 2014, the top ten sports medicine journals were determined based on current impact factors. The impact factor is a measure of the frequency with which the "average article" in a journal has been cited in a particular year or period and can be used to provide a general understanding of the prestige of a journal. ${ }^{7}$ Journal impact factors are regularly calculated by the Institute for Scientific Information (ISI) and published in the Journal Citation Reports (JCR).

For this review, sports medicine journal impact factors were extracted from the ISI Web of knowledge, JCR 2012.8 These highest impact-factor sports medicine journals were searched within the last five years i.e. January 2009 to December 2013 for publications which purported to be about clinical guidelines, using the keyword 'guideline' (see Table 1). Given the many changes which have occurred in the last five years in the way sports medicine has been delivered,, 910 this time frame was considered to be reflective of opportunities to incorporate research evidence into practice.

Peer-reviewed papers providing clinical recommendations that were described by the authors as a guideline were included. For the purpose of this review, guideline was defined as "... systematically developed statements to assist practitioner and patient decisions about appropriate health care for specific clinical circumstances" and was required to state a clear method for obtaining underlying evidence. ${ }^{11}$ Where the method of obtaining evidence was not research-based (i.e. it relied on expert or consensus opinion) the outcome was classified as a consensus statement. Consensus statements were only included if they were termed guidelines as per publication. Two assessors (ZM \& LP) performed an initial search of titles and abstracts using the inclusion criteria. After the initial search, full text versions of articles were retrieved and a final assessment of eligibility was made. Any disagreements regarding eligibility of articles were resolved through discussion with the third author (KG). Articles were classified as presenting clinical guidelines and/or consensus statements, based on the definition above.

Two assessors (ZM \& LP) evaluated clinical guideline quality using the International Centre for Allied Health Evidence (iCAHE) Guideline Checklist.6,12 This appraisal tool was used because its intent was to be an efficient, simple tool for clinicians, policy-

(c) The Internet Journal of Allied Health Sciences and Practice, 2015 
makers, administrators, consumers, researchers and guideline developers to assess core elements of guideline construction and implementation.

\section{RESULTS}

Table 1 summarizes the characteristics and impact factors of the selected sports medicine journals.

Table 1. Top ten sports medicine journals as per the ISI Web of knowledge: Journal Citation reports (2012)

\begin{tabular}{|l|l|l|l|l|}
\hline $\begin{array}{l}\text { Impact } \\
\text { Factor }\end{array}$ & \multicolumn{1}{|c|}{ Journal } & $\begin{array}{l}\text { Issues } \\
\text { per } \\
\text { year }\end{array}$ & \multicolumn{1}{|c|}{ Country } & \multicolumn{1}{|c|}{ Website } \\
\hline 5.283 & $\begin{array}{l}\text { Exercise \& Sport } \\
\text { Sciences Reviews }\end{array}$ & 4 & United States & $\begin{array}{l}\text { http://journals.Iww.com/acsm- } \\
\text { essr/pages/default.aspx?WT.mc_id=EMxj18x20101026xL8 }\end{array}$ \\
\hline 5.237 & Sports Medicine & 12 & New Zealand & http://link.springer.com/journal/40279 \\
\hline 4.475 & $\begin{array}{l}\text { Medicine \& Science in } \\
\text { Sports \& Exercise }\end{array}$ & 12 & United States & http://journals.Iww.com/acsm-msse/pages/default.aspx \\
\hline 4.439 & $\begin{array}{l}\text { American Journal of } \\
\text { Sports Medicine }\end{array}$ & 12 & United States & http://ajs.sagepub.com/ \\
\hline 3.668 & $\begin{array}{l}\text { British Journal of Sports } \\
\text { Medicine }\end{array}$ & 12 & England & http:///bjsm.bmj.com/ \\
\hline 3.214 & $\begin{array}{l}\text { Scandinavian Journal of } \\
\text { Medicine \& Science in } \\
\text { Sports }\end{array}$ & 6 & Denmark & $\begin{array}{l}\text { http:///onlinelibrary.wiley.com/journal/10.1111//ISSN)1600- } \\
\text { 0838 }\end{array}$ \\
\hline 2.947 & $\begin{array}{l}\text { Journal of Orthopedic \& } \\
\text { Sports Physical } \\
\text { Therapy }\end{array}$ & 12 & United States & http://www.jospt.org/ \\
\hline 2.899 & $\begin{array}{l}\text { Journal of Science \& } \\
\text { Medicine in Sport }\end{array}$ & 6 & Australia & http://www.jsams.org/ \\
\hline 2.384 & $\begin{array}{l}\text { Clinics in Sports } \\
\text { Medicine }\end{array}$ & 4 & United States & http://www.sportsmed.theclinics.com/ \\
\hline 2.268 & $\begin{array}{l}\text { International Journal of } \\
\text { Sports Medicine }\end{array}$ & 8 & Germany & $\begin{array}{l}\text { https://www.thieme- } \\
\text { connect.com/products/ejournals/journal/10.1055/s- } \\
\text { 00000028 }\end{array}$ \\
\hline
\end{tabular}

Considering the last five years, there were 34 potentially-relevant publications identified from these journals (reported in Appendix 1). ${ }^{13-46}$ From this pool, ten publications met the inclusion criteria (See Figure 1). Eleven of the 24 excluded publications were experimental studies and the remaining publications were conference abstracts, clinical commentaries, editorials or literature reviews. Six journals did not publish or feature a publication which could be considered a clinical guideline. Of the ten included publications, eight $15,20,26,39-43$ addressed musculoskeletal injuries, one addressed cardiology screening 37 and one concerned glycerol use in reference to hyper-hydration and re-hydration (Table 2). ${ }^{46}$ 
Figure 1. Search Results

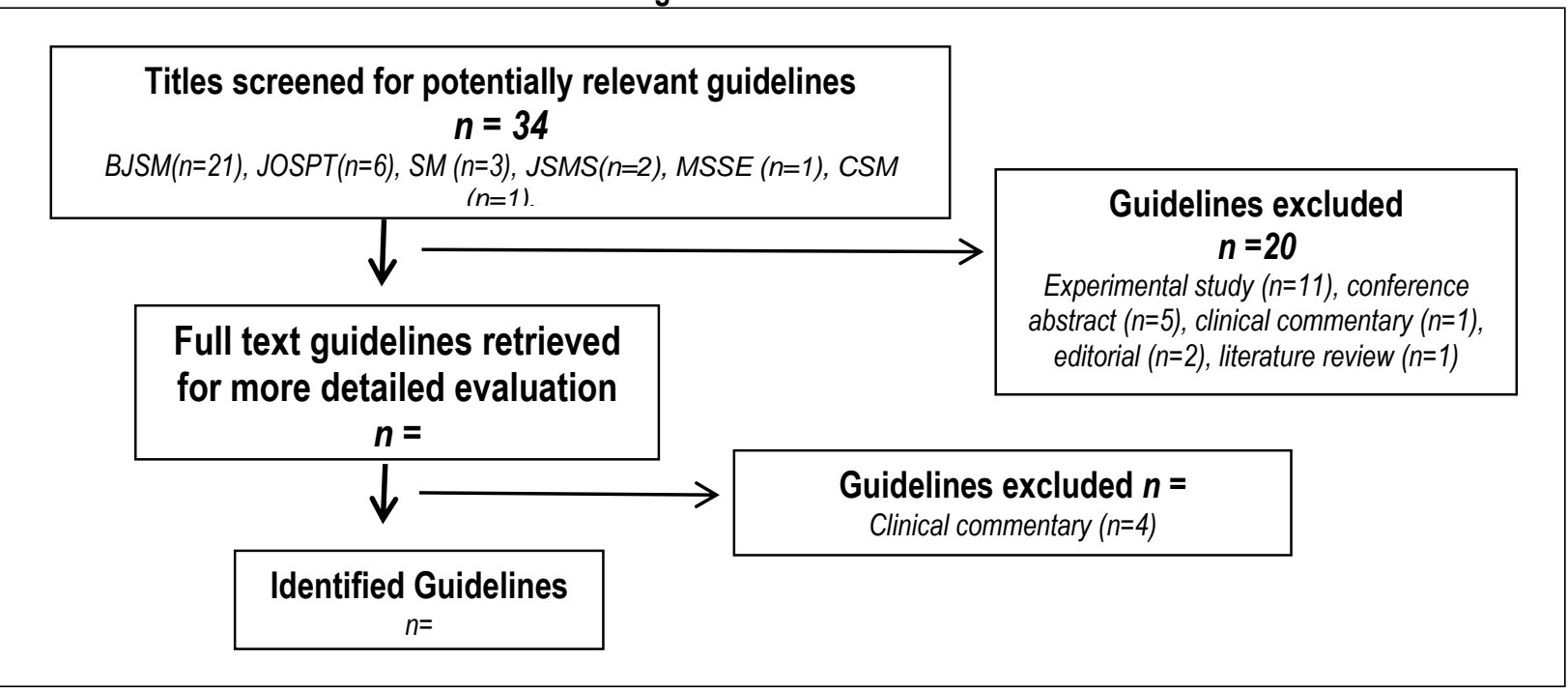

BJSM: British journal of Sports Medicine JSMS: Journal of Science and Medicine in Sport MSSE: Medicine \& Science in Sports \& Exercise CSM: Clinics in Sports Medicine JOSPT: Journal of Orthopaedic \& Sports Physical Therapy

Table 2. Clinical guidelines identified in the search

\begin{tabular}{|c|c|c|}
\hline Authors \& Date & Guideline Title & Journal \\
\hline $\begin{array}{l}\text { van Rosendal et. } \\
\text { al. } 2010^{46}\end{array}$ & $\begin{array}{l}\text { Guidelines for glycerol use in hyperhydration \& rehydration associated with } \\
\text { exercise }\end{array}$ & Sports Medicine \\
\hline $\begin{array}{l}\text { Kerkhoffs et. al. } \\
2012^{26}\end{array}$ & $\begin{array}{l}\text { Diagnosis, treatment \& prevention of ankle sprains: an evidence-based } \\
\text { clinical guideline }\end{array}$ & $\begin{array}{l}\text { British Journal of Sports } \\
\text { Medicine }\end{array}$ \\
\hline $\begin{array}{l}\text { Hoogvliet et. al } \\
2013^{15}\end{array}$ & $\begin{array}{l}\text { How to treat Guyon's canal syndrome? Results from the European } \\
\text { Handguide study: a multidisciplinary treatment guideline }\end{array}$ & $\begin{array}{l}\text { British Journal of Sports } \\
\text { Medicine }\end{array}$ \\
\hline $\begin{array}{l}\text { Fowell \& Earl } \\
2013^{20}\end{array}$ & Return-to-play guidelines following facial fractures & $\begin{array}{l}\text { British Journal of Sports } \\
\text { Medicine }\end{array}$ \\
\hline $\begin{array}{l}\text { Gaunt et. al. } \\
2010^{39}\end{array}$ & $\begin{array}{l}\text { The American Society of Shoulder and Elbow Therapists' Consensus } \\
\text { Rehabilitation Guideline for Arthroscopic Anterior Capsulolabral Repair of the } \\
\text { Shoulder }\end{array}$ & $\begin{array}{l}\text { Journal of Orthopaedic \& } \\
\text { Sports Physical Therapy }\end{array}$ \\
\hline $\begin{array}{l}\text { Logerstedt et. al. } \\
2010^{43}\end{array}$ & Knee Stability \& Movement Coordination impairments: Knee Ligament Sprain & $\begin{array}{l}\text { Journal of Orthopaedic \& } \\
\text { Sports Physical Therapy }\end{array}$ \\
\hline $\begin{array}{l}\text { Logerstedt et. al. } \\
2010^{42}\end{array}$ & $\begin{array}{l}\text { Knee Pain and Mobility Impairments: Meniscal \& } \\
\text { Articular Cartilage Lesions }\end{array}$ & $\begin{array}{l}\text { Journal of Orthopaedic \& } \\
\text { Sports Physical Therapy }\end{array}$ \\
\hline $\begin{array}{l}\text { Delitto et. al. } \\
2012^{41}\end{array}$ & Low Back Pain & $\begin{array}{l}\text { Journal of Orthopaedic \& } \\
\text { Sports Physical Therapy }\end{array}$ \\
\hline $\begin{array}{l}\text { Cibulka et. al. } \\
200940\end{array}$ & Hip Pain and Mobility Deficits - Hip Osteoarthritis & $\begin{array}{l}\text { Journal of Orthopaedic \& } \\
\text { Sports Physical Therapy }\end{array}$ \\
\hline $\begin{array}{l}\text { Angadi \& } \\
\text { Gaesser } 2009^{37}\end{array}$ & $\begin{array}{l}\text { Pre -Exercise Cardiology Screening Guidelines for Asymptomatic Patients } \\
\text { with Diabetes }\end{array}$ & $\begin{array}{l}\text { Clinics in Sports } \\
\text { Medicine }\end{array}$ \\
\hline
\end{tabular}

Quality appraisal scores ranged from three to 11 out of 14 (see Table 3). The most frequent identified methodological concerns related to evaluation of the evidence underlying each clinical recommendation. Failure to adequately describe the search 
strategy that was used to source evidence, and failure to appraisal the quality of the underlying evidence were common. Indeed, only one guideline performed a quality appraisal of the included evidence. ${ }^{46}$ Furthermore, all guidelines failed to link the hierarchy with the quality of evidence underpinning each recommendation. This meant that there was no transparency for guideline users regarding the choice and interpretation of evidence, upon which to base clinical decisions.

Within the 10 included publications, three could be classified as consensus statements (Hoogvliet et. al. 2013,15 Angadi \& Gaesser 2009,37 Fowell \& Earl 201337). Reflected in the quality scores, two consensus statements scored the lowest scores, three and four respectively. ${ }^{20,37}$ The third consensus statement ${ }^{15}$ employed a Delphi consensus technique, based on experts' opinion and incorporated a systematic evaluation of the underlying evidence base prior to obtaining expert opinions and thus received a moderate score.

Table 3. Quality Assessment Scores

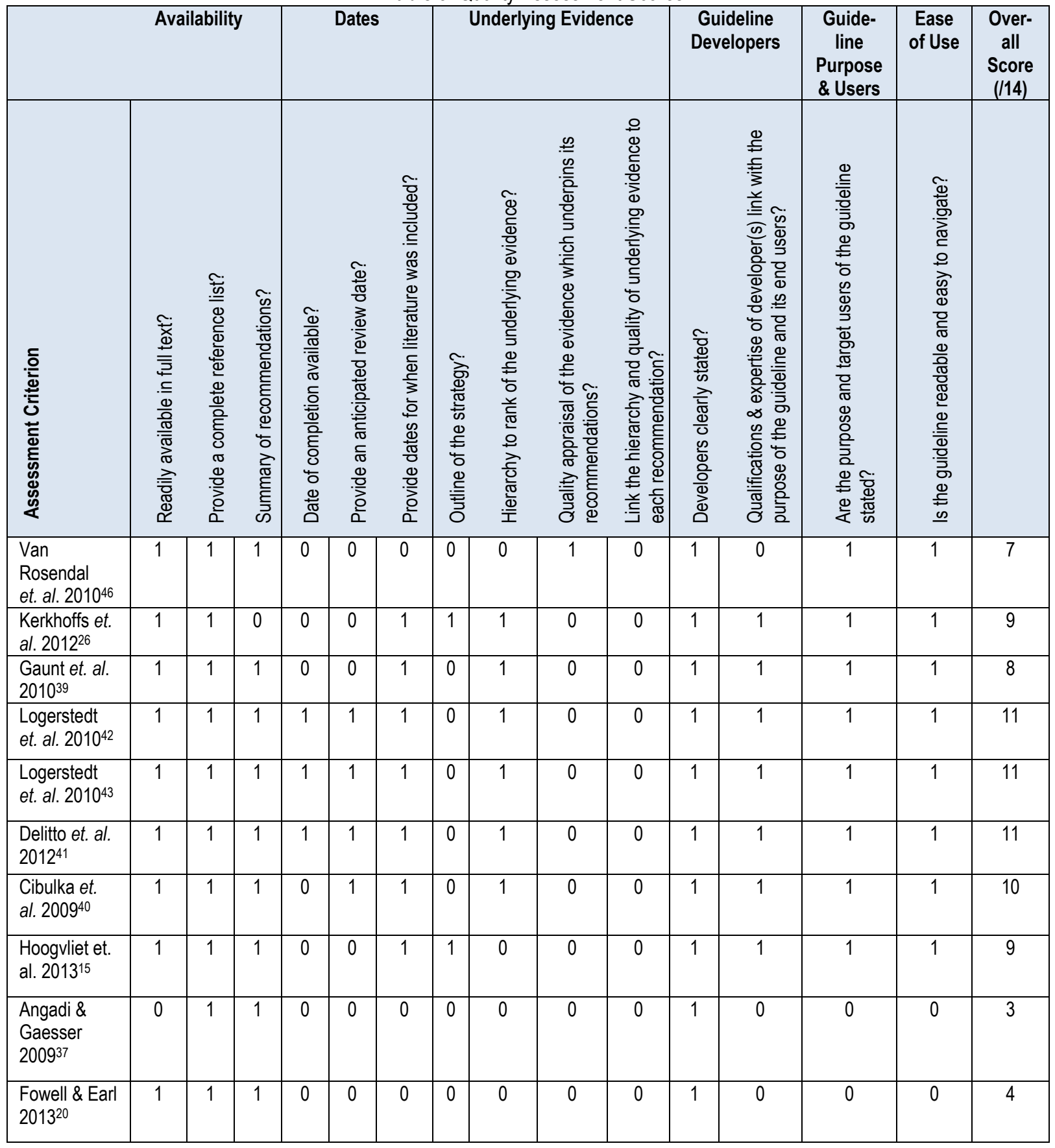




\section{DISCUSSION}

To our knowledge, this is the first study to provide an overview of the availability of clinical practice guidelines in sports medicine, in peer reviewed journals.

Clinical guidelines published in the top 10 sports medicine journals based on current impact factors within the last five years Considering the exponential growth in the number of sports medicine publications in the last decade, ${ }^{47}$ the number of clinical guidelines available in peer-reviewed journal in this period of time was surprisingly small. Misclassification of what was actually being reported; in papers purporting to describe clinical guidelines was identified in three consensus statements. For the reason that only 10 journals were reviewed, there may be other journals which report sports medicine guidelines which were not included in this search. However, by including journals with the highest impact factors, we assumed that these would be the most influential and the most read sources of research evidence.

\section{Methodological Quality}

The methodological quality of the clinical guidelines identified in this review was poor to moderate. Common methodological problems related to the assessment of the underlying evidence and development of recommendations. Transparent methodology in guideline development is essential to ensure that the risk of bias is minimised; therefore, the recommendations provided by any of these guidelines should be considered with caution.

\section{What's in a Name}

Consensus statements are often badged as clinical guidelines and may refer broadly to research evidence. However, unlike a clinical guideline, a consensus statement does not provide evidence of rigorous, high quality, transparent and independent evaluation of the evidence, nor does it link the hierarchy and quality of underlying evidence to each of its recommendations. This review identified three ${ }^{15,20,37}$ consensus statements that were titled as clinical guidelines and one clinical guideline that was additionally titled as a consensus statement. ${ }^{26}$ As defined and discussed above, the methodology and evidence base underpinning each recommendation behind clinical guidelines and consensus statements differs greatly. Sports medicine clinicians should become familiar with the differences between the two, as both these types of documents have the potential to influence clinical decision making and can prove to be useful tools in assisting in evidence based practice. As demonstrated by this review, the iCAHE guideline checklist can potentially highlight consensus statements, reflective in low quality appraisal scores.

This review identified a limited number of published guidelines in sports medicine journals; where many clinicians may go to find research evidence and clinical practice recommendations. In sports medicine, expert opinion sometimes represents the best, or only, available evidence. Where very limited research has been published in a particular area, a consensus statement may be the most appropriate resource.

Consider the example of concussion in sport: The recent revised consensus statement for the diagnosis and management of concussion in sport provides recommendations derived from the deliberations of world leaders during an international conference on concussion in sport, held in Zurich in $2012 .{ }^{48}$ Now in its third update, this consensus statement provides a summary of current literature and expert opinions and provides the reader with recommendations to help guide clinical practice and increase patient safety. A reason for the wide acceptance of a consensus statement in this field is that concussion research can be difficult to carry out due to the methodological complexities such as obtaining an adequate sample size, randomising subjects into treatment arms, and blinding patients and researchers.

The big issue with consensus statements is that they are dependent on the presence of experts. Experts may differ in their views and experiences, and unless an expert panel contains broad and balanced views, the resulting consensus statement may be influenced by the loudest voices. When a good-quality clinical guideline and a consensus statement are available for the management of a condition, sports clinicians should preference the clinical guideline, on the basis that it is less likely to contain biased or erroneous recommendations. Once a good-quality clinical guideline has been developed, it cannot be replaced by a consensus statement. All future upgrades to the guideline recommendation should be undertaken using the same developmental processes as the original guideline. Where a consensus statement is the only available evidence, its biases should be clearly stated. In particular, the reasons for developing the consensus statement, and the attempts that the development team made to identify and synthesise the best available evidence should be described.

Although this review aimed to identify, assess and quantify currently published sports medicine clinical guidelines from a sample of internationally-recognised peer-reviewed sports medicine journals, it should be acknowledged that full-text guidelines may be too large (100 pages for a guideline is not uncommon) for publication in a journal. As such, there are a number of internationally-

(c) The Internet Journal of Allied Health Sciences and Practice, 2015 
recognised groups that develop high-quality clinical guidelines, including guidelines that would be of interest to the sports medicine clinician. Below is a list of such websites which would be useful for the sports medicine field. These websites contain clinical guidelines for hundreds of clinical conditions, and the breadth of the clinical guidelines they provide is not only vast but also provides an access point for those wishing to obtain a clinical guideline.

Table 4. Clinical Guidelines Websites

\begin{tabular}{|l|l|}
\hline The Scottish Intercollegiate Guideline Network (SIGN) & [http://www.sign.ac.uk/] \\
\hline The National Institute of Clinical Excellence (NICE) & [http://www.nice.org.uk/] \\
\hline The New Zealand Guidelines Group (NZGG) & hhttp://www.health.govt.nz/about-ministry/ministry-health- \\
websites/new-zealand-guidelines-group]
\end{tabular}

\section{CONCLUSION}

This review identified only low to moderate quality clinical guidelines currently published in well-credentialed sports medicine journals. There exists some confusion of guidelines with consensus statements, clinical commentaries and literature reviews as a source of high level evidence-based clinical recommendations. Sports medicine clinicians should therefore become aware of the difference of these types of documents and be able to independently assess their quality. Future iterations of clinical guidelines in the field of sports medicine should endeavor to appraise the quality of included literature and clearly link recommendations to the underlying evidence base.

\section{REFERENCES}

1. Brukner P, Khan K. Brukner \& Khan's clinical sports medicine, $4^{\text {th }}$ ed. North Ryde, N.S.W: McGraw-Hill Australia; 2012.

2. Grol R. Has guideline development gone astray? Yes. BMJ. 2010;340:c306. [PMID 20118175]

3. Burgers JS, Cluzeau FA, Hanna SE, Hunt C, Grol R. Characteristics of high-quality guidelines: evaluation of 86 clinical guidelines developed in ten European countries and Canada. Int J Technol Assess Health Care. 2003 winter; 19(1):148-57. [PMID 12701947]

4. Eccles M, Grimshaw J, Shekelle P, Schünemann H, Woolf S. Developing clinical practice guidelines: target audiences, identifying topics for guidelines, guideline group composition and functioning and conflicts of interest. Implementation Science. 2012;7:60. [PMID 22762776]

5. Brouwers MCP, Kho MEBM, Browman GPMDM, Burgers JSMDP, Cluzeau FP, Feder GMD, et al. AGREE II: advancing guideline development, reporting and evaluation in health care. Prev Med. 2010 Nov;51(5):421-4. [PMID 20728466]

6. Grimmer K, Dizon JM, Milanese S, King E, Beaton K, Thorpe O, et al. Efficient clinical evaluation of guideline quality: development and testing of a new tool. BMC Med Res Methodol. 2014;14:63 [PMID 24885893]

7. Bordons M, Fernández MT, Gómez I. Advantages and limitations in the use of impact factor measures for the assessment of research performance. Scientometrics. 2002;53(2):195-206.

8. The Institute for Scientific Information knowledge. Journal Citation Reports. 2012 [April 6th 2014]; Available from: http://admin-apps.webofknowledge.com.ezlibproxy.unisa.edu.au/JCR/JCR.

9. McEwan IM, Taylor WG. 'When do I get to run on with the magic sponge?' The twin illusions of meritocracy and democracy in the professions of sports medicine and physiotherapy. Qualitative Research in Sport and Exercise. 2010;2(1):77-91.

10. Brukner PD, Crossley KM, Morris H, Bartold SJ, Elliott B. 5. Recent advances in sports medicine. Medical Journal of Australia. 2006;184(4):188-93. [PMID 16489907]

11. Feild M, Lohr KN. Clinical practice guidelines: direction of a new program. Washington DC: National Academy Press; 1990.

12. Grimmer-Somers K, Worley A. Practical tips for using and developing guidelines: An allied health primer. University of Santo Tomas Publishing House; 2010.

13. Panhuyzen-Goedkoop NM, Smeets JL. Legal responsibilities of physicians when making participation decisions in athletes with cardiac disorders: Do guidelines provide a solid legal footing? Br J Sports Med. 2014;48(15):1193-5. [PMID 24668047]

14. Titchener AG, Booker SJ, Bhamber NS, Tambe AA, Clark DI. Corticosteroid and platelet-rich plasma injection therapy in tennis elbow (lateral epicondylalgia): a survey of current UK specialist practice and a call for clinical guidelines. Br J Sports Med. 2013 Nov 6. bjsports-2013-092674 Published Online First: 6 November 2013 [PMID 24195919]

15. Hoogvliet P, Coert JH, Fridén J, Huisstede BMA, European HANDGUIDE group. How to treat Guyon's canal syndrome? Results from the European HANDGUIDE study: a multidisciplinary treatment guideline. Br J Sports Med. 2013;47(17):106370. [PMID 23902776] 
16. Rosimus C, Currell K. The Development, Feasibility and Efficacy of Hydration Guidelines in Elite Cricket. Br J Sports Med. 2013;47(17):e4.

17. Wall $B A$, Watson $G$, Peiffer JJ, Abbiss $C R$, Siegel R, Laursen PB. Current hydration guidelines are erroneous: dehydration does not impair exercise performance in the heat. Br J Sports Med. 2013 Sep 20. [PMID 24055782]

18. Gawroński W, Sobiecka J, Malesza J. Fit and healthy Paralympians-medical care guidelines for disabled athletes: a study of the injuries and illnesses incurred by the Polish Paralympic team in Beijing 2008 and London 2012. Br J Sports Med. 2013;47(13):844-9. [PMID 23902777]

19. Tayeb R. Diagnostic value of Ottawa ankle rules: simple guidelines with high sensitivity. Br J Sports Med. 2013;47(10):e3.

20. Fowell CJ, Earl P. Return-to-play guidelines following facial fractures. Br J Sports Med. 2013;47(10):654-6. [PMID 23410884]

21. Dunlop M, Murray AD. Major limitations in knowledge of physical activity guidelines among UK medical students revealed: implications for the undergraduate medical curriculum. Br J Sports Med. 2013;47(11):718-20. [PMID 23314886]

22. Gjestland K, Bø K, Owe KM, Eberhard-Gran M. Do pregnant women follow exercise guidelines? Prevalence data among 3482 women, and prediction of low-back pain, pelvic girdle pain and depression. Br J Sports Med. 2013;47(8):515-20. [PMID 22904295]

23. Madsen NL, Drezner JA, Salerno JC. Sudden cardiac death screening in adolescent athletes: an evaluation of compliance with national guidelines. Br J Sports Med. 2013;47(3):172-7. [PMID 23118118]

24. Finch CF, McCrory P, Ewing MT, Sullivan SJ. Concussion guidelines need to move from only expert content to also include implementation and dissemination strategies. Br J Sports Med. 2013;47(1):12-4. [PMID 23060652]

25. Weiler R, Chew S, Coombs N, Hamer M, Stamatakis E. Physical activity education in the undergraduate curricula of all UK medical schools. Are tomorrow's doctors equipped to follow clinical guidelines? Br J Sports Med. 2012;46(14):1024-6. [PMID 22846233]

26. Kerkhoffs GM, van den Bekerom M, Elders LA, van Beek PA, Hullegie WA, Bloemers GM, et al. Diagnosis, treatment and prevention of ankle sprains: an evidence-based clinical guideline. Br J Sports Med. 2012;46(12):854-60. [PMID 22522586]

27. Bahr R, Reeser JC. New guidelines are needed to manage heat stress in elite sports - The Fédération Internationale de Volleyball (FIVB) Heat Stress Monitoring Programme. Br J Sports Med. 2012;46(11):805-9. [PMID 22685120]

28. Cook I, Alberts M, Lambert EV. Compliance with physical activity guidelines in rural, black South Africans in the Limpopo Province: an energy expenditure approach. Br J Sports Med. 2011;45(8):619-25. [PMID 21427124]

29. McGall SE, McGuigan MR, Nottle C. Contribution of free play towards physical activity guidelines for New Zealand primary school children aged 7-9 years. Br J Sports Med. 2011;45(2):120-4. [PMID 19696036]

30. Redgrave A, Gallen I, Hudson Z. Establishing practical guidelines for exercise in insulin treated diabetics. Br J Sports Med. 2011;45(2):e1.

31. Paoloni JA, Milne $C$, Orchard J, Hamilton B. Non-steroidal anti-inflammatory drugs in sports medicine: guidelines for practical but sensible use. Br J Sports Med. 2009;43(11):863-5. [PMID 19546098]

32. Khan KM. Hip labral tears, economics in sports medicine and guidelines for NSAID use. Br J Sports Med. 2009;43(8):547. [PMID 19661284]

33. Purcell L. What are the most appropriate return-to-play guidelines for concussed child athletes? Br J Sports Med. 2009;43(Suppl 1):i51-i5. [PMID 19433426]

34. van Wier M, Verweij L, Proper K, Hulshof C, van Tulder M, van Mechelen W. Economic evaluation of an occupational health guideline for prevention of weight gain among employees. Journal of Science and Medicine in Sport. 2012;15:S238. [PMID 23969508]

35. Finch C, Gabbe B, Lloyd D, Cook J, Young W, Nicholson M, et al. The design of a study to better understand facilitators and barriers towards safety guideline uptake-The NoGAPS project. Journal of Science and Medicine in Sport. 2011;14:e4-e5.

36. Greaves CJ. Preventing Type 2 Diabetes: Recommendations On Achieving Lifestyle Change From The Image Guideline Development Project. Med Sci Sports Exerc. 2009;41(5):416.

37. Angadi SS, Gaesser GA. Pre-Exercise Cardiology Screening Guidelines for Asymptomatic Patients with Diabetes. Clinics in Sports Medicine. 2009;28(3):379-92. [PMID 19505622]

38. Edwards PK, Ackland T, Ebert JR. Clinical Rehabilitation Guidelines for Matrix-Induced Autologous Chondrocyte Implantation on the Tibiofemoral Joint. Journal of Orthopaedic \& Sports Physical Therapy. 2014;44(2):102-19. [PMID 24175609]

39. Gaunt BW, Shaffer MA, Sauers EL, Michener LA, McCluskey III GM, Thigpen CA. The American Society of Shoulder and Elbow Therapists' Consensus Rehabilitation Guideline for Arthroscopic Anterior Capsulolabral Repair of the Shoulder. Journal of Orthopaedic \& Sports Physical Therapy. 2010;40(3):155-68. [PMID 20195022]

40. Cibulka MT, White DM, Woehrle J, Harris-Hayes M, Enseki K, Fagerson TL, et al. Hip Pain and Mobility Deficits - Hip Osteoarthritis: Clinical Practice Guidelines Linked to the International Classification of Functioning, Disability, and Health

(c) The Internet Journal of Allied Health Sciences and Practice, 2015 
from the Orthopaedic Section of the American Physical Therapy Association. Journal of Orthopaedic \& Sports Physical Therapy. 2009;39(4):A1-A25. [PMID 19352008]

41. Delitto A, George SZ, Van Dillen L, Whitman JM, Sowa G, Shekelle P, et al. Low Back Pain. Journal of Orthopaedic \& Sports Physical Therapy. 2012;42(4):A1-A57. [PMID 22466247]

42. Logerstedt DS, Snyder-Mackler L, Ritter RC, Axe MJ, Godges J. Knee Pain and Mobility Impairments: Meniscal and Articular Cartilage Lesions. Journal of Orthopaedic \& Sports Physical Therapy. 2010;40(6):A1-597. [PMID 20511698]

43. Logerstedt DS, Snyder-Mackler L, Ritter RC, Axe MJ, Godges JJ. Knee Stability and Movement Coordination Impairments: Knee Ligament Sprain. Journal of Orthopaedic \& Sports Physical Therapy. 2010;40(4):A1-A37. [PMID 20357420]

44. O'Hagan C, De Vito G, Boreham CG. Exercise prescription in the treatment of type 2 diabetes mellitus: current practices, existing guidelines and future directions. Sports Medicine. 2013;43(1):39-49. [PMID 23315755]

45. Zavorsky G, Longo L. Exercise Guidelines in Pregnancy: new perspectives. Sports Medicine. 2011;41(5):345-60. [PMID 21510713]

46. van Rosendal SP, Osborne MA, Fassett RG, Coombes JS. Guidelines for glycerol use in hyperhydration and rehydration associated with exercise. Sports Medicine. 2010;40(2):113-3. [PMID 20092365]

47. Machotka Z. Science and medicine in sport publications: What are the current trends? Journal of Science and Medicine in Sport. 2010;12:e49-e50.

48. McCrory P, Meeuwisse WH, Aubry M, Cantu B, Dvořák J, Echemendia RJ, et al. Consensus statement on concussion in sport: the 4th International Conference on Concussion in Sport held in Zurich, November 2012. Br J Sports Med. 2013 April 1, 2013;47(5):250-8. [PMID 23479479]

\section{KEY TERMS}

Clinical practice guideline, consensus statement, sports medicine, evidence based medicine 
Appendix A

Details on Potentially-Relevant Articles

\begin{tabular}{|c|c|c|c|}
\hline Journal & Author details & Included & Excluded \\
\hline \multirow{21}{*}{$\begin{array}{l}\text { British Journal of Sports } \\
\text { Medicine }\end{array}$} & Panhuyzen \& Smeets $2014^{13}$ (13) & & Editorial \\
\hline & Titchener et. al. $2013^{14}$ & & Experimental study \\
\hline & Hoogvliet et. al. $2013^{15}$ & See Table 2 & \\
\hline & Rosimus \& Currell $2013^{16}$ & & Conference abstract \\
\hline & Wall et. al. $2013^{17}$ & & Experimental study \\
\hline & Gawronski et. al. $2013^{18}$ & & Experimental study \\
\hline & Tayeb $2013^{19}$ & & Conference abstract \\
\hline & Fowell \& Ear|20 & See Table 2 & \\
\hline & Dunlop \& Murray $2012^{21}$ & & Experimental study \\
\hline & Gjestland et. al. $2013^{22}$ & & Experimental study \\
\hline & Madsen et. al. $2012^{23}$ & & Experimental study \\
\hline & Finch et. al. $2013^{24}$ & & Clinical Commentary \\
\hline & Weiler et. al. $2012^{25}$ & & Experimental study \\
\hline & Kerkhoffs et. al. $2012^{26}$ & See Table 2 & \\
\hline & Bahr \& Reeser $2012^{27}$ & & Experimental study \\
\hline & Cook et. al. 201128 & & Experimental study \\
\hline & McGall et. al. $2011^{29}$ & & Experimental study \\
\hline & Redgrave et. al. $2011^{30}$ & & Experimental study \\
\hline & Paoloni et. al. 200931 & & Clinical Commentary \\
\hline & Khan 200932 & & Editorial \\
\hline & Purcell $2009^{33}$ & & Literature review \\
\hline \multirow{2}{*}{$\begin{array}{l}\text { Journal of Science and Medicine } \\
\text { in Sport }\end{array}$} & Van Wier et. al. $2012^{34}$ & & Conference abstract \\
\hline & Finch et. al. $2011^{35}$ & & Conference abstract \\
\hline $\begin{array}{l}\text { Medicine and Science in Sports } \\
\text { and Exercise }\end{array}$ & Greaves et. al. $2009^{36}$ & & Conference abstract \\
\hline Clinics in Sports Medicine & Angadi \& Gaesser 200937 & See Table 2 & \\
\hline \multirow{6}{*}{$\begin{array}{l}\text { Journal of Orthopaedic and } \\
\text { Sport Physical Therapy }\end{array}$} & Edwards et. al. $2014^{38}$ & & Clinical Commentary \\
\hline & Gaunt et. al. $2010^{39}$ & See Table 2 & \\
\hline & Cibulka et. al. 200940 & See Table 2 & \\
\hline & Delitto et. al. $2012^{41}$ & See Table 2 & \\
\hline & Logerstedt et. al. $2010^{42}$ & See Table 2 & \\
\hline & Logerstedt et. al. $2010^{43}$ & See Table 2 & \\
\hline \multirow[t]{3}{*}{ Sports Medicine } & O'Hagan et. al. $2013^{44}$ & & Clinical Commentary \\
\hline & Zavorsky \& Longo45 & & Clinical Commentary \\
\hline & Van Rosendal et. al . $2010^{46}$ & See Table 2 & \\
\hline
\end{tabular}

